Detka Karolina, Gruszka Jakub, Zwierzyńska Anna, Dolecka-Ślusarczyk Magdalena, Adamczyk-Gruszka Olga. Parents' knowledge of neonatal transitory conditions and their expectations of the midwife. Journal of Education, Health and Sport. 2021;11(12):210-225. eISSN 2391-8306. DOI http://dx.doi.org/10.12775/JEHS.2021.11.12.015

https://apcz.umk.pl/JEHS/article/view/JEHS.2021.11.12.015

https://zenodo.org/record/5783852

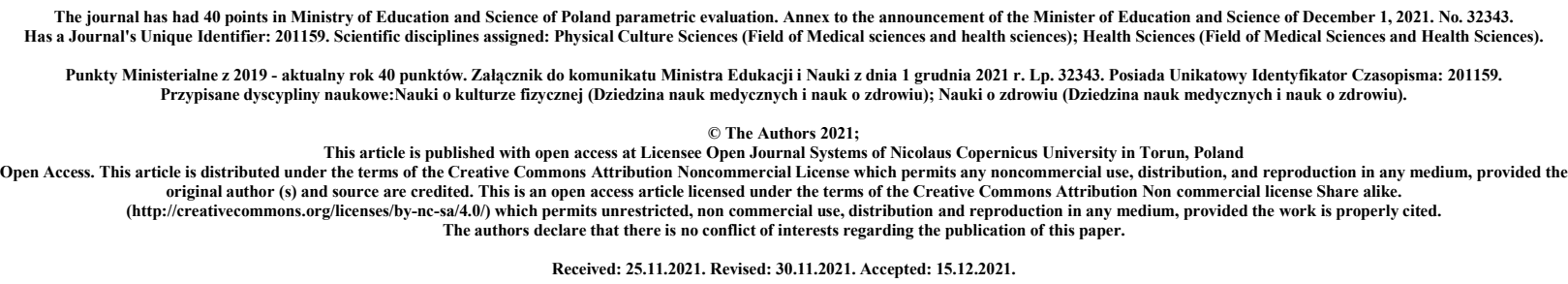

\title{
Parents' knowledge of neonatal transitory conditions and their expectations of the midwife
}

\section{Karolina Detka}

Department of Gynaecology and Obstetrics, Provincial Integrated Hospital in Kielce, Poland https://orcid.org/0000-0001-9002-568X

\section{Jakub Gruszka}

II Department and Clinic of Obstetrics and Gynaecology, Medical University of Warsaw, Poland https://orcid.org/0000-0001-9701-4502

\section{Anna Zwierzyńska}

Collegium Medicum, Jan Kochanowski University, Kielce, Poland https://orcid.org/0000-0002-4913-8620

\section{Magdalena Dolecka-Ślusarczyk}

Department of Internal Medicine, Voivodeship Combined Hospital in Kielce; Collegium Medicum, Jan Kochanowski University in Kielce https://orcid.org/0000-0002-0742-0337

\section{Olga Adamczyk-Gruszka}

Department of Gynaecology and Obstetrics, Collegium Medicum, Jan Kochanowski University, Kielce, Poland; Department of Gynaecology and Obstetrics, Provincial Integrated Hospital in Kielce, Poland https://orcid.org/0000-0003-1295-009X 


\section{Streszczenie}

\section{Wstęp}

Okres noworodkowy jest okresem przystosowania dziecka do życia poza organizmem matki. W tym czasie dziecko musi przystosować się do zmian zachodzących w jego organizmie. Po porodzie noworodek oceniany jest wg skali Apgar, która jest stosowana do prognozowania jego późniejszego rozwoju.

\section{Cel pracy}

Celem pracy była ocena wiedzy rodziców na temat stanów przejściowych noworodków, poznanie ich oczekiwań względem personelu medycznego.

\section{Material i metody}

W badaniu wzięło udział 248 kobiet z województwa świętokrzyskiego. Mieszkanki dużych miast stanowiły $64,5 \%$ ankietowanych, a 16,2\% badanych to mieszkanki pochodzące ze środowiska wiejskiego. Kobiety powyżej 35 roku życia stanowiły 46,8\% pacjentek, 19,3\% to pacjentki między 26 a 30 rokiem życia. Również 19,3\% stanowiły pacjentki między 30 a 35 rokiem życia. Poniżej 25 roku życia było 14,6\%.

Badanie zostało zatwierdzone przez Komisję Bioetyczną UJK.

Analizę statystyczną przeprowadzono za pomocą programu komputerowego Statistica.

\section{Wyniki}

Wiedzę na temat czasu trwania okresu noworodkowego posiadało $81 \%$ kobiet. Respondentki w $62 \%$ znały wpływ witaminy $\mathrm{K}$ zapobiegającej wystąpieniu choroby krwotocznej u noworodka. Połowa kobiet preferuje karmienie na żądanie, natomiast $42 \%$ respondentek uważa, że należy to robić od 6 do 8 razy na dobę. Duży problem wśród położnic stanowi brak dostępu do psychologa. Ankietowane uważają, że w trudnej sytuacji chciałaby uzyskać wsparcie zespołu interdyscyplinarnego.

\section{Wnioski}

Rodzice nie potrafią rozpoznać stanów przejściowych u noworodka. Edukacja przedporodowa przyszłych matek ma wpływ na ich zachowania prozdrowotne i może się przyczynić do zapobiegania wystąpienia nieprawidłowości w rozwoju dziecka. Rodzice czerpią 
swoją wiedzę na temat noworodków od rodziny, znajomych posiadających dzieci, poradników i książek.

Słowa kluczowe: stany przejściowe noworodka, przebieg ciąży, stan kliniczny noworodka po porodzie

\section{Abstract}

\section{Introduction}

The neonatal period is the period of the child's adaptation to life outside the mother's body. The child has to adapt to the changes taking place in its body. After delivery, the new-born baby is assessed according to the Apgar scale.

\section{Objective of the study}

The objective of the study was to assess the parents' knowledge of the transitory conditions of neonates and to identify their expectations towards medical personnel.

\section{Material and methods}

248 women participated in the study. Inhabitants of large cities accounted for $64.5 \%$ of the respondents and $16.2 \%$ of the respondents were inhabitants of rural areas. Women aged over 35 accounted for $46.8 \%$ of patients, $19.3 \%$ were patients between the ages of 26 and 30. Patients between the ages of 30 and 35 also accounted for 19.3\%. Patients under 25 years of age accounted for $14.6 \%$.

The Bioethics Committee approved the project.

Statistical analysis was performed with the use of the Statistica computer program.

\section{Results}

$81 \%$ of women displayed knowledge about the duration of the neonatal period. $62 \%$ of the respondents knew the effect of vitamin $\mathrm{K}$ in preventing the occurrence of haemorrhagic disease in the neonate. Half of the women prefer to feed on demand. A big problem among women in childbed is the lack of access to a psychologist.

\section{Conclusions}

Parents cannot recognize transitory conditions in a neonate. Antenatal education of future mothers influences their pro-health behaviour. Parents source their knowledge from their family, friends, guides and books.

Keywords: neonatal transitory conditions, course of pregnancy, clinical condition of the neonate after delivery 


\section{Introduction}

The neonatal period, i.e., the time of the first month after birth, is the period of the child's adaptation to life outside the mother's body. It lasts up to 28 days. Then the child has to adapt to changes: temperature, breathing pattern, new way of taking food and its defecation [1]. After delivery, the neonate baby is assessed by medical staff in the 1st, 3rd, 5th and 10th minute of life

according to the Apgar scale, which is used to predict its later development $[2,3,4]$. This scale assesses basic life functions, such as heart function, breathing, skin colour, muscle reflexes and tonicity. A child may receive a maximum of 10 points on this scale $[5,6]$. The condition of a neonate baby is assessed as good if it receives from 8 to 10 points, average if it receives 4 to 7 points, poor - below 4 points [7].

In the neonatal phase, there occur reflexes which arise as a result of reactions to external stimuli. These include the following reflexes: oral, sucking, swallowing, seeking, as well as tonic, cervical, ocular, grasping reflex of upper and lower limbs, Moro (embracing) reflex, Babinski reflex, Rossolimo reflex and walking reflex [7].

Upon its birth, a neonate baby possesses developed organs for hearing, sight and sense of touch. Phonation appears in a neonate with its first cry after birth [8]. In the first days of life, the body mass of a neonate decreases, which is related to the physiological weight loss, which should not exceed $10 \%$ of the birth weight [9]. Between the 3rd and 4th day of life, a neonate reaches its lowest weight, which is compensated for around the 8th day of life. Physiological body mass decrease is caused by loss of water through the lungs and skin, urination, meconium, drying umbilical cord, loss of fluid, insufficient food and vomiting [10,11,12]. Healthy neonates should begin to gain weight from the 6th day of life, and from the 14th day of life their weight should exceed their birth weight and stabilize [10].

Physiological jaundice of neonates is treated as a process of adaptation of the digestive and hepatic systems to extrauterine life. The discoloration of the skin - usually yellow - appears between the 2 nd and $3 \mathrm{rd}$ day of life, when the highest concentration of total bilirubin is 13-15 $\mathrm{mg} / \mathrm{dl}(22.3-256.5 \mu \mathrm{m} / \mathrm{l})$ in the body. Physiologically, this state lasts up to 7 days $[10,13]$. Statistical data indicates that this problem affects $50-70 \%$ of full-term and approximately $80 \%$ of premature infants $[14,15,16]$. The appearance of jaundice is influenced by increased bilirubin production as a result of the increase in the body mass of the neonate in the following days, shorter lifetime of erythrocytes and their increased breakdown, enzymatic immaturity of the liver 
and obstructed bile outflow $[9,13,16]$. The general condition of the neonate does not usually deteriorate; it may be drowsier, less active and gain weight more slowly $[14,17]$.

The neonate's first stool, called meconium, is a sticky, dense, dark green mass which appears during the first 24 hours of life. In the following days, it turns brown, which is associated with a change in the diet and feeding with milk. The number of stools passed in a day ranges from 3 to 7, while in neonates fed with mother's milk there may be a dozen or so stools after each meal [9].

Toxic erythema affects $30-70 \%$ of neonates, it occurs most frequently on the skin in the 1 st day of life, appearing in the form of small papules with a red rim and a white centre. It recedes without treatment within a week. The causes of its occurrence include the mother's hormones, increased metabolism, and sensitivity of the skin, which is not adapted to new conditions [10].

After being born, the neonate has to adapt to the cold external environment. The production of heat as a result of the activation of metabolic processes helps the neonate, because the mechanisms related to muscle and motor activity have not yet been developed. As a result of disturbance of the thermoregulation centres which appear after birth, the body temperature drops. A physiological increase in body temperature may appear on the 3rd or 4th day of a neonate's life, when its body mass decreases $[10,18]$. The reasons are: a small amount of food, bacteria penetrating the digestive tract, immaturity of the nervous system. The temperature then rises to $38-39^{\circ} \mathrm{C}$ and may persist for several hours. During this period, the infant is restless; the mucous membranes are dry and red. This applies to $2 \%$ of neonates. [18].

In some neonates, both female and male, between the 2nd and 3rd day of life, the mammary glands become enlarged as a result of the accumulation of secretions, with their composition resembling that of sulphur. The reason for this phenomenon is the hormones passed from mother to infant. As a result of the action of the mother's hormones, female infants experience enlargement of the clitoris and appearance of bloody vaginal discharge. This state may persist for several months after delivery [10].

Vitamin K plays an important role in the synthesis of blood coagulation factors. Its passage through the placenta is limited, which results in its physiological deficiency during the first days of a neonate's life, leading to a temporary reduction of coagulation factors [10]. Between the 3rd and 5th day of life, a neonate may suffer from intracranial, gastrointestinal, navel, lung and 
mucosal bleeding caused by the deficiency of this vitamin. Other causes of bleeding in neonates include infections, sepsis, concomitant metabolic diseases, and Kasabach-Merritt syndrome. Bleeding disorders affect naturally fed babies and preterms with hepatic diseases. In order to prevent bleeding, a neonate is given vitamin $\mathrm{K}$ [19].

Birth schools help in antenatal education, the primary purpose of which is to prepare parents for parenthood. Antenatal education is considered to be a comprehensive collection of psychophysical issues related to pregnancy and its course, childbirth and the early period after childbirth [20]. The process of educating women should begin at the beginning of pregnancy in specialist gynaecology and obstetrics offices $[21,22,23]$. Future mothers should be familiarized with the changes that will take place in their body during pregnancy and puerperium, as well as with the methods of relaxation. It is necessary to provide information about the available forms of medical care during pregnancy and postpartum, promote positive behaviour, present ways to establish emotional contact with the child after delivery, prepare a pregnant woman for childbirth and postpartum psychophysically, develop appropriate parental attitudes, present a correct procedure of caring for and feeding a neonate [24,25,26,27].

Since 2012, a regulation has been in force in Poland on the standards of perinatal care, i.e., Regulation of the Minister of Health on standards of medical procedure in the provision of perinatal care services provided to women during physiological pregnancy, physiological delivery, postpartum and care for a neonate baby. This document specifies in detail the rules of caring for a pregnant woman during childbirth and postpartum [28]. In recent years, considerable emphasis has been placed on conscious motherhood. Educational programs are being developed: Birth Schools, School of Mothers and Fathers, Together Easier, Breastfeeding Promotion Program, and Initiatives undertaken by the Child Friendly Hospital [22]. The role of a midwife is crucial for parents. It is professional medical help during childbirth and postpartum [29,30]. Systematic observation of the woman and her emotional state is very important, as is the Beck's score, which, if negative, may have an impact on the occurrence of postpartum depression [25,31]. The main tasks of a midwife include educating future parents, care during pregnancy, childbirth and postpartum, caring for a neonate and infant up to 2 months of age, counselling on nutrition for women during pregnancy and postpartum, counselling for neonate care, counselling with regard to lactation, breastfeeding, vaccination education, taking measurements of a neonate and their assessment, assessment of family relations with a neonate, monitoring a neonate's 
development [32]. At home, postnatal check visits are conducted by a family and community midwife. A midwife should make at least four postnatal check visits, during which she instructs parents how to develop a bond with the baby and how to apply breastfeeding properly. During the visits, she measures the infant, assesses its physical development and neonatal reflexes. She is obliged to detect pathologies in the family and provide counselling in coping with stressful situations [28]. The midwife takes care of the child up to the age of 6 weeks and then transfers it to the care of a primary healthcare nurse $[31,33]$.

\section{Objective of the study, material and methods}

The objective of the study was to assess the parents' knowledge of the transitory conditions of neonates and to learn about their expectations towards medical personnel.

248 women from Świętokrzyskie Province participated in the study. Inhabitants of large cities with population over 50,000 accounted for $64.5 \%$ of the respondents, $19.3 \%$ were respondents from small and medium-sized cities, and $16.2 \%$ of the respondents were inhabitants of rural areas. Women over age of 35 accounted for $46.8 \%$ of patients, $19.3 \%$ were patients between the ages of 26 and 30 . There were $19.3 \%$ of patients between the age of 30 and 35 , and only $14.6 \%$ of women under 25 years of age.

The obtained results were subjected to the $\mathrm{Chi}^{2}$ test, also known as the Pearson's chisquared test.

The number of children born to the participants of the survey: of the surveyed women, $36 \%$ have one child, $29 \%$ two children, $19 \%$ three children, $16 \%$ of the respondents have over three children.

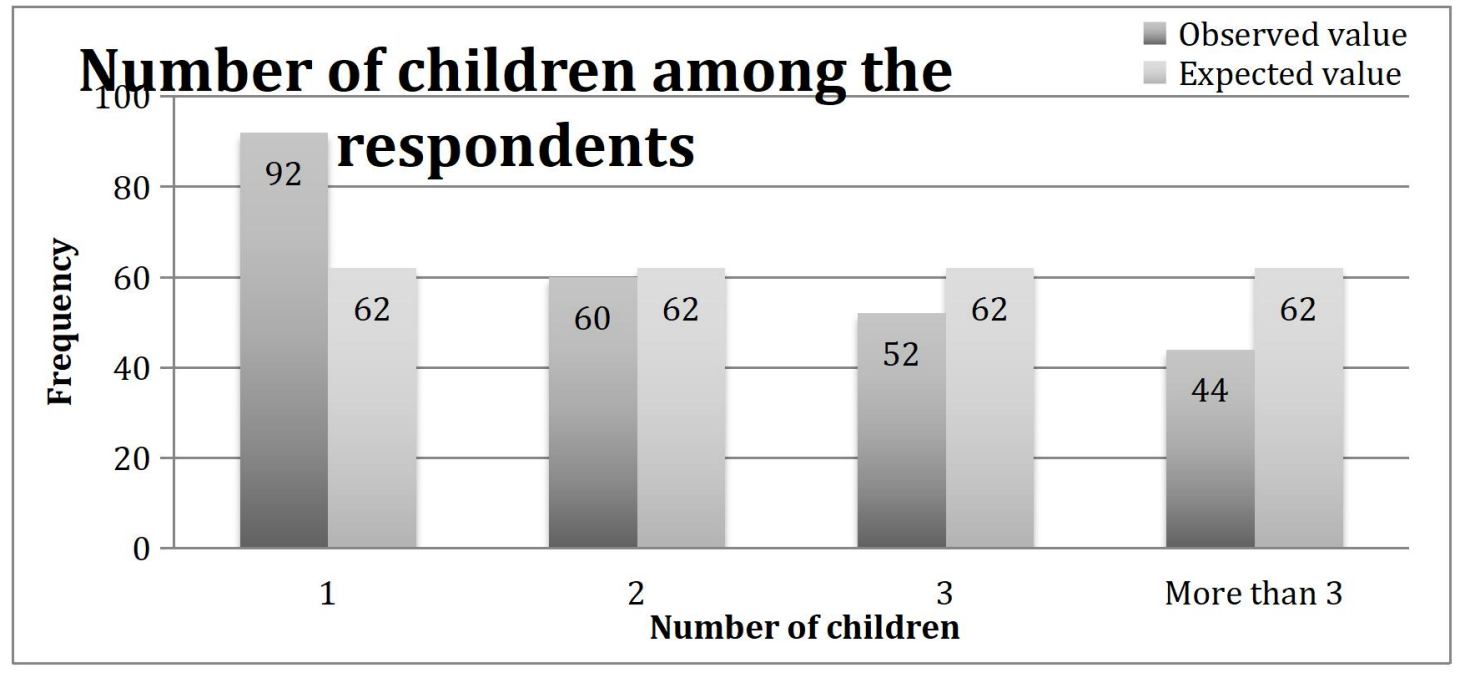

Fig. 1. Number of children among the respondents 
As many as $81 \%$ of women have knowledge about the duration of the neonatal period. Incorrect data whereby this period lasts 3 months was indicated by $16 \%$ of women, and 2 months - by $3 \%$.

Information on the influence of vitamin $\mathrm{K}$ on the prevention of haemorrhagic disease in the neonate was reported by $62 \%$ of respondents, $8 \%$ admitted that they had no information on this subject, and $31 \%$ of people indicated that they knew of its properties.

Breastfeeding is an indispensable part of everyday life. $40 \%$ of women indicated breastfeeding a child on demand. A comparable group of $42 \%$ of women stated that it should be done 6-8 times a day, and $8 \%$ of respondents believed that the infant's crying is the signal to feed the baby.

The sources of information about a neonate baby, concerning its nursing and care, were obtained by the women from guidebooks, from their family or friends who have children, on the Internet, from a doctor or childbirth school. A midwife was the least frequently indicated source.

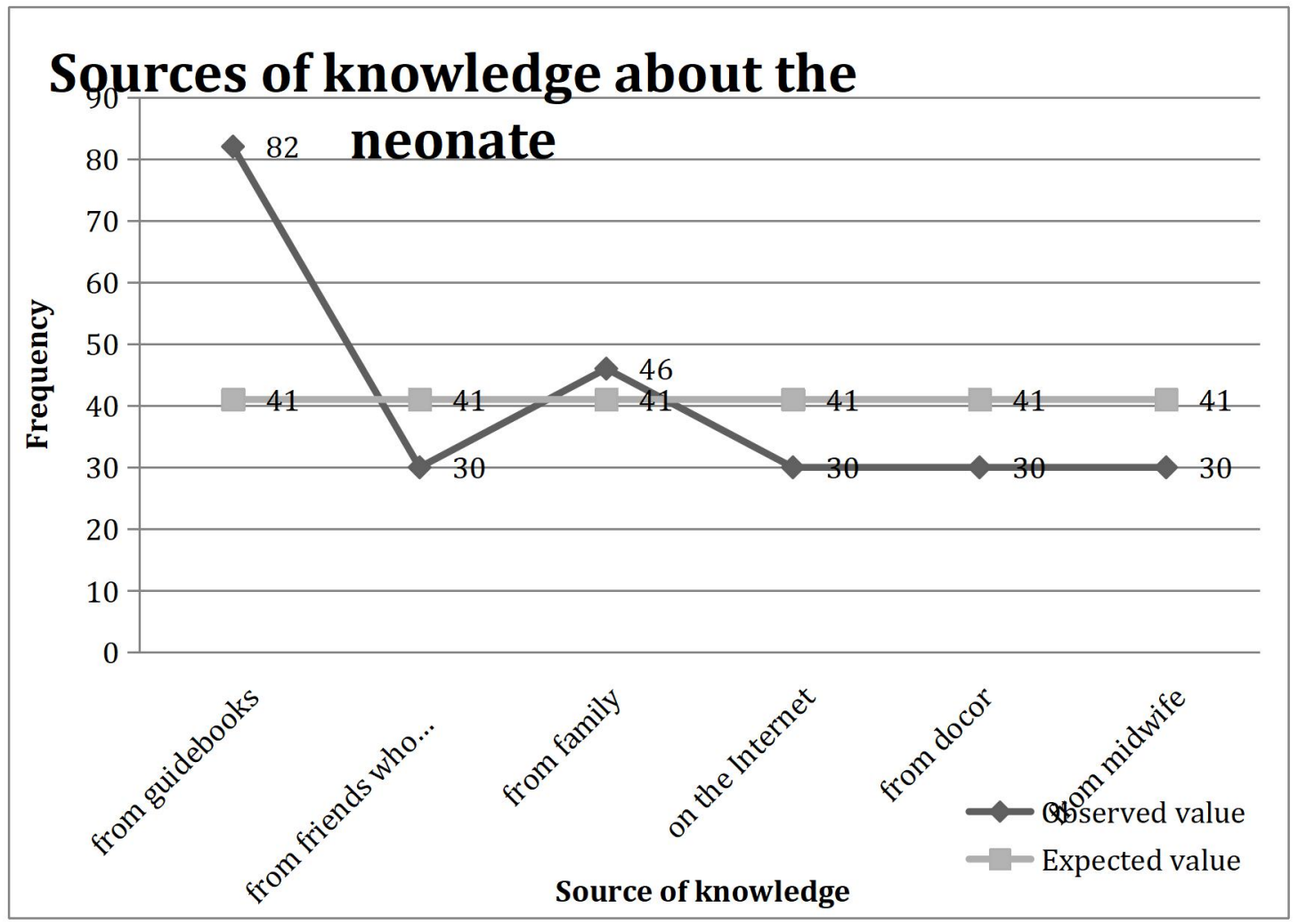

Fig. 2. Sources of knowledge about the neonate.

The factors motivating the respondents to start childbirth education included obtaining information that would allow future parents to prepare for being a responsible parent, acquiring 
the skills to properly care for a neonate, acquiring breastfeeding skills, and involving a partner or child's father in caregiving.

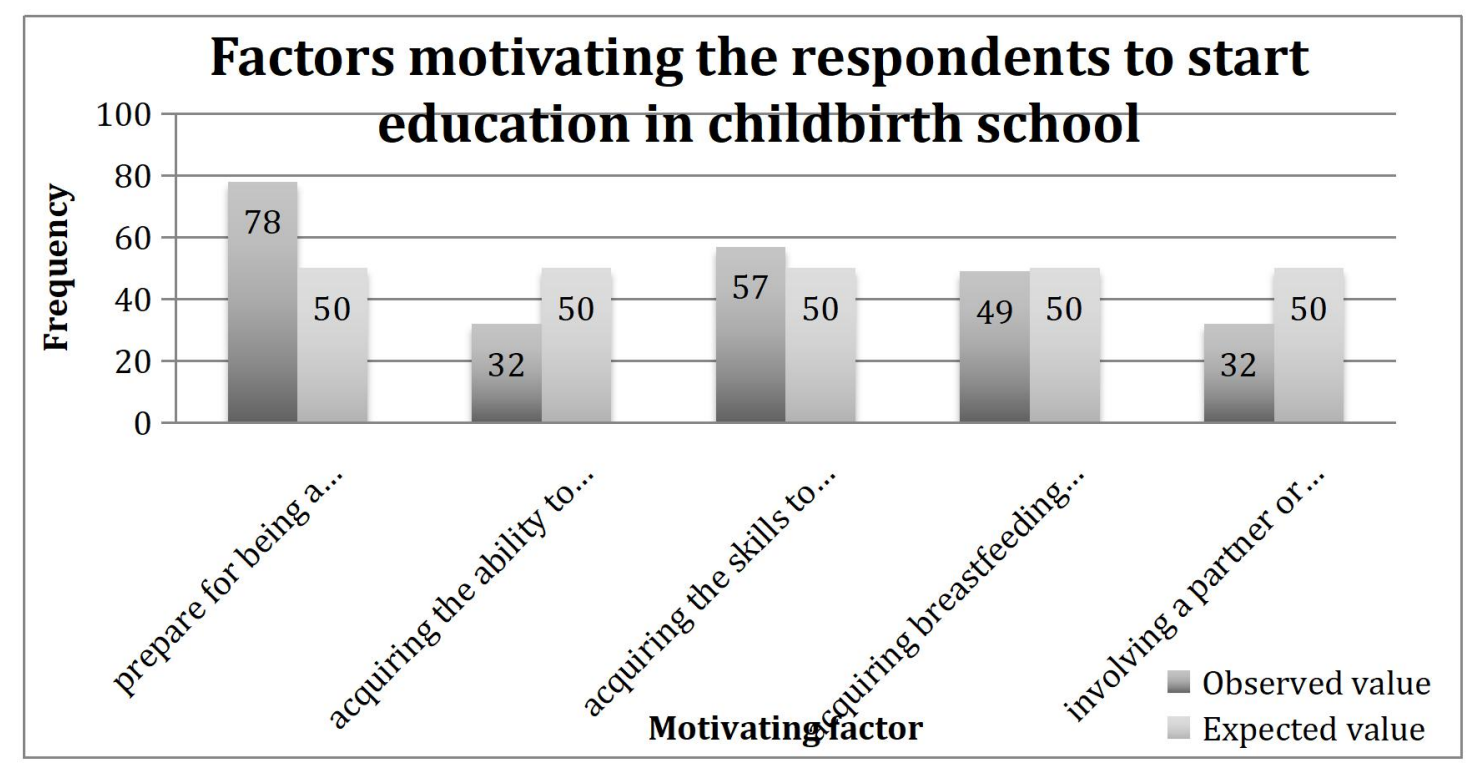

\section{Fig. 3. Factors motivating the respondents to start education in childbirth school}

Only one third of the respondents knew what the transitory conditions of a neonate are, while half of them admitted that they did not know what to do or how to behave in the case of any irregularities occurring.

180 respondents acquired this knowledge on their own, the remaining part stated that it was insignificant.

Another problem among the respondents was the question of what qualified as the neonate's transitory conditions. The answers of the female respondents are presented in Figure 4. 


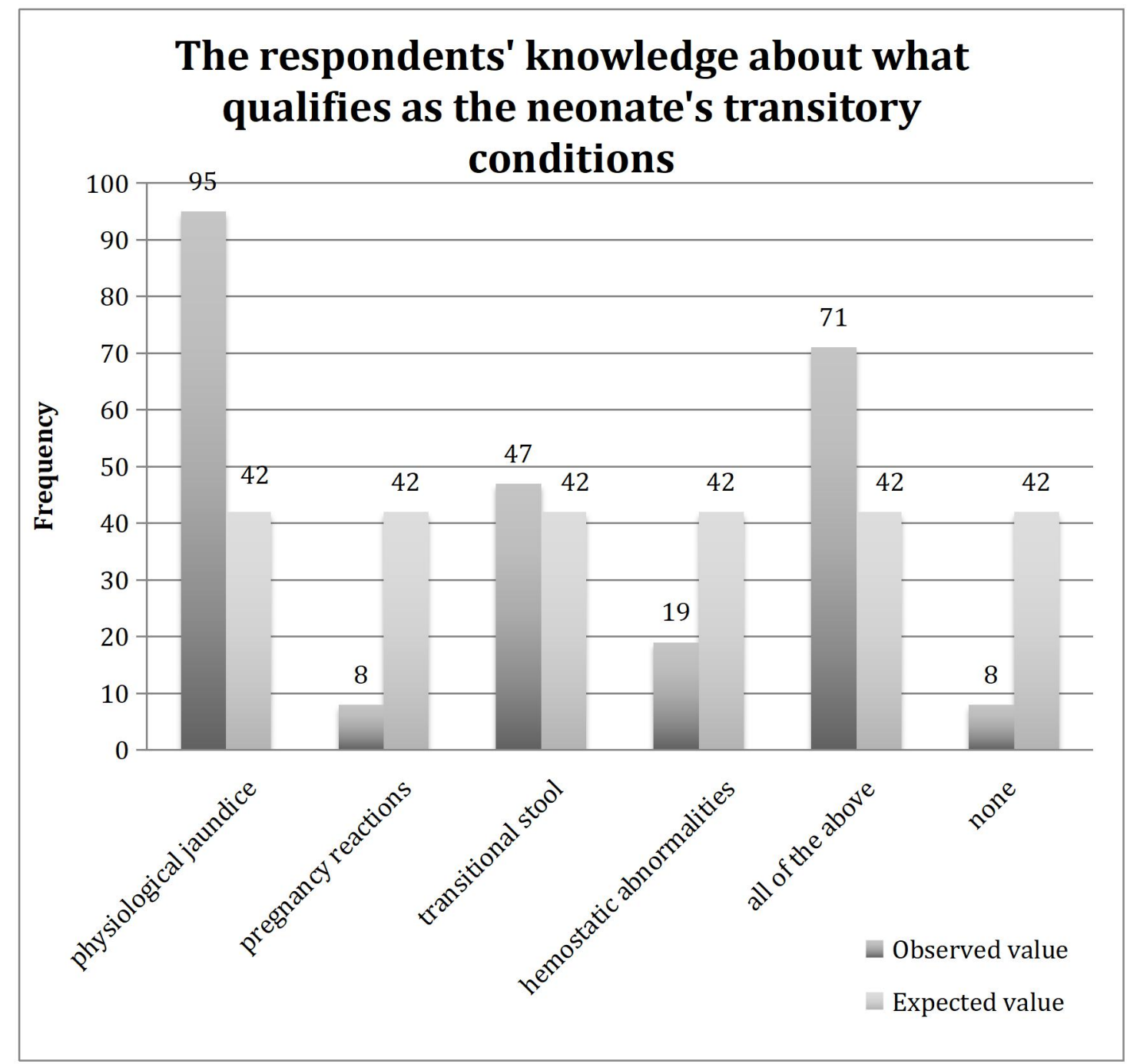

Fig. 4. The respondents' knowledge about what qualifies as the neonate's transitory conditions

The parents' awareness of how to behave in the event of a transitory condition was minimal, only $25 \%$ of the women knew how to act. The results concerning neonatal reflexes were similar. Only $6 \%$ of the respondents knew what neonatal reflexes are, $62 \%$ did not know exactly what they are, and as many as $32 \%$ did not have any knowledge in this regard. The results of the research prove the necessity of propagating basic information concerning the transitory conditions of the neonatal phase among parents.

Another problem concerned the expectations of parents in relation to the midwife. Some of the respondents wanted to obtain knowledge on how to care for a neonate, another group was interested in gaining information on transitory conditions and pathologies of the neonate. The test results are shown in Figure 5. 


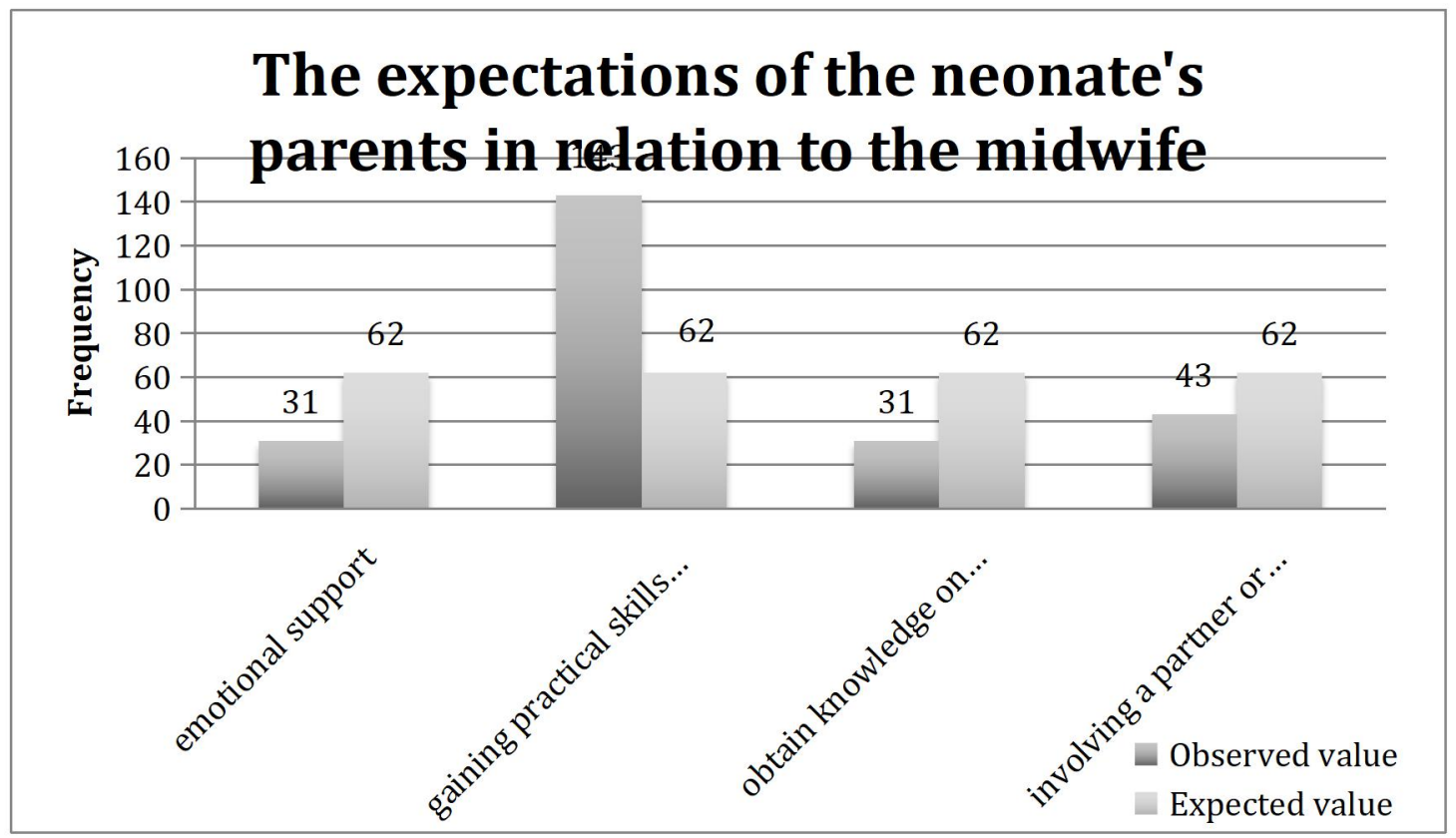

Fig. 5. The expectations of the neonate's parents in relation to the midwife

Most of the respondents, i.e., as many as 164, pointed to the importance of a midwife in the transmission of information, with 8 women indicating no such importance. The most desirable trait was honesty and a clear message, the positive attitude of the medical staff was considered to be the least important. 63 women wanted information from a midwife on how to care for a neonate, 55 about coping with stress, 43 about diet and nutrition during pregnancy, 12 about physical activity, and 75 respondents required answers to all the above-mentioned questions. Among the parents, more than half of the respondents believe that the midwife should provide them with psychological care, and $29 \%$ claim that in a difficult situation they would like to receive support from an interdisciplinary-perinatal team (doctor, midwife, psychologist, geneticist). Only $13 \%$ of women in such a situation expect support from a clergyman.

The study of the relationship between the patients' knowledge of the transitory conditions of the neonate, the number of their offspring, possessed knowledge about the neonate transitory conditions, attendance of a birth school, and the methods of obtaining information on this subject were calculated on the basis of a series of analyses of the $\mathrm{Chi}^{2}$ test of independence and the Pearson correlation coefficient (PCC). On this basis, when comparing the Cramer's V measure with Pearson's statistical analysis, it can be concluded that acquiring and obtaining information about the knowledge on neonates provide a significant statistical result, which should affect the 
knowledge of the respondents about the neonate's transitory conditions. The parents' awareness of how to proceed during the transitory condition presented a statistically significant result of $\mathrm{p}=$ 0.006 and in the case of neonatal reflexes $\mathrm{p}<0.001$, which indicates the significance of the results. Table 1. shows the results of calculations based on Pearson's tests for the analysed correlations.

\section{Table 1. Have you heard about neonatal transitory conditions?}

Table 1

Have you heard about neonatal transitory conditions?

\begin{tabular}{|ccccc|}
\hline & $\mathrm{x}^{2}$ & $\mathrm{df}$ & $\mathrm{P}$ & $\mathrm{V}$ \\
\hline Source of information & 53,41 & 6 & $<0.001$ & 0.23 \\
\hline $\begin{array}{c}\text { Number of the respondent's } \\
\text { children }\end{array}$ & 21,42 & 4 & $<0.001$ & 0.17 \\
\hline Birth school & 29,64 & 5 & $<0.001$ & 0.17 \\
\hline The respondents' knowledge & 155.14 & 6 & $<0.001$ & 0.40 \\
\hline
\end{tabular}

$x^{2}-C h i^{2}$ statistic of independence, $d f$ - number of degrees of freedom, p-level of statistical significance, the strength of dependence measured with Cramer's V coefficient

All studies using Pearson's tests showed statistically insignificant relationships between knowledge and participation in birth school $\mathrm{x}^{2}=29.64, \mathrm{p}<0.001, \mathrm{~V}=0.17$. The attendants of birth school did not have much information on this topic. Statistically insignificant correlations in this topic were found.

Comparing the results of Pearson's statistical analysis with the Cramer's V coefficient, it was concluded that the source of the obtained information and the number of offspring did not matter. The fact that parents gain knowledge about the transitory conditions is important, as shown in Cramer's V test.

An important element is an awareness of the parents' behaviour during the transitory condition of the neonate, which was confirmed by the statistical dependence of the $\mathrm{Chi}^{2}$ test with the result of $\mathrm{p}<0.001 / \mathrm{p} 0.05$, which is the desired result when we want to obtain a statistically significant relationship.

\section{Conclusions}

Based on the analysis of the research results, it was found that the parents' knowledge of the neonate's transitory conditions was insufficient. The parents were unable to discern the basic 
transitory conditions, expecting assistance, involvement, and emotional support from a midwife, and the information provided by her is essential for the child's development.

Prenatal education of pregnant women has a decisive impact on their health-promoting behaviour and may also contribute to preventing abnormalities in the child's development. The respondents expect the midwife to provide information on activities related to the prevention, care, and upbringing of a neonate.

Parents' knowledge of neonatal transitory conditions varies and is not affected by age, place of residence, or the number of their offspring. Most women have heard about the neonate transitory conditions, but only a small percentage of the respondents have detailed information on the phenomenon in question. Parents possess knowledge of the subject gained from family, friends with children, guidebooks and other literature.

Parents claim that a midwife should make more than 4 postnatal check visits to families with a neonate. Almost all respondents admitted that the cooperation of a midwife with a patient is of great importance in neonatal care.

\section{Bibliography}

1. Kielar-Turska M, Białecka-Pikul M. Wczesne dzieciństwo, [w:] Psychologia rozwoju człowieka. Charakterystyka okresów życia (red.) B. Harwas-Napierała, J. Trempała, PWN, Warszawa, 2004; s. 27-28.

2. American Academy of Pediatrics, Committee on Fetus and Newborn; American College of Obstetricians and Gynecologists and Committee on Obstetric Practice. The Apgar score. Pediatrics. 2006 Apr;117(4):1444-7. doi: 10.1542/peds.2006-0325. PMID: 16585348.

3. Baskett TF. Virginia Apgar and the newborn Apgar score. Resuscitation. 2000 Nov;47(3):215-7. doi: 10.1016/s0300-9572(00)00340-3. PMID: 11114450.

4. Casey BM, McIntire DD, Leveno KJ. The continuing value of the Apgar score for the assessment of newborn infants. $\mathrm{N}$ Engl J Med. 2001 Feb 15;344(7):467-71. doi: 10.1056/NEJM200102153440701. PMID: 11172187.

5. Gruszfeld D. Badania noworodka. Przewodnik Lekarski. 2008; 2: 32-38.

6. Pearce JM. Virginia Apgar (1909-1974): neurological evaluation of the newborn infant. Eur Neurol. 2005;54(3):132-4. doi: 10.1159/000089084. PMID: 16244485.

7. Michałowicz R, Chmieli J. Okres noworodkowy dziecka w ocenie neurologicznopediatrycznej. PZWL. Warszawa 2006: 89-90. 
8. Michalak R. Neurokognitywne uwarunkowania przestrzeni rozwoju dziecka. W: KrauzeSikorska H, Klichowska M, Świat małego dziecka. Wyd. UAM, Poznań, 2017: 15-33.

9. Kwiatkowska-Król A. Stany przejściowe u noworodka. Źródło: https://ohme.pl/macierzynstwo/stany-przejsciowe-u-noworodka-ktore-swiadcza-o-fizjologiia-patologii/ - data dostępu 10.05.2021

10. Augustyniuk K. Stany przejściowe występujące u noworodka. Biuletyn edukacyjnoinformacyjny dla Personelu Medycznego oddziałów Położniczych i Neonatologicznych. 2011; 10: 4-6.

11. Knowles V, Yajamanyam PK. Physiological weight loss in term newborn infants. Arch Dis Child. 2021 Feb;106(2):195-197. doi: 10.1136/archdischild-2020-319158. Epub 2020 Oct 6. PMID: 33023887.

12. Szilagyi-Pągowska I. Auksologia. Medycyna Praktyczna Pediatria. 2002; 2: 127-134.

13. Gadzinowski J, Szymankiewicz M, et al. Podstawy neonatologii. Oddział Wielkopolski Polskiego Towarzystwa Medycyny Perinatalnej. Poznań, 2014: 11-17.

14. Czerwionka-Szaflarska M, Nowak A. Przedłużająca się żółtaczka u noworodków i niemowląt- o czym należy myśleć? Przegląd Pediatryczny. 2007; 37(4): 383- 387.

15. Kornacka MK, Tołłoczko J. Hiperbilirubinemia okresu noworodkowego- problem stale aktualny. Postępy Neonatologii. 2008; 1: 55-61.

16. Sankaran K, Perlman M. Żółtaczka noworodka. W: Kirpalani H, Moore AM, Perlman M. Podręcznik neonatologii. Medipage. Warszawa 2009: 203-222.

17. Mitra S, Rennie J. Neonatal jaundice: aetiology, diagnosis and treatment. Br J Hosp Med (Lond). 2017 Dec 2;78(12):699-704. doi: 10.12968/hmed.2017.78.12.699. PMID: 29240507.

18. Perlman J, Kjaer K. Neonatal and Maternal Temperature Regulation During and After Delivery. Anesth Analg. 2016 Jul;123(1):168-72. doi: 10.1213/ANE.0000000000001256. PMID: 27314693.

19. Dobrzańska A, Helwich E, Lukas W, et al. Zalecenia zespołów ekspertów dotyczące profilaktyki krwawienia $\mathrm{z}$ niedoboru witaminy $\mathrm{K}$ u noworodków i niemowląt. Standardy Medycyny. 2007; 4: 6-8.

20. Balaskas J. Poród aktywny. Nowe spojrzenie na naturalne sposoby rodzenia. Nowa, Warszawa, 2000: 15-23. 
21. Augustyniuk K, Rudnicki J, Grochans E. Standard edukacji poporodowej realizowanej w Szkole Matek i Ojców na oddziale neonatologiczno-położniczym. Perinatologia, Neonatologia i Ginekologia. 2012; 5(1): 46-50.

22. Mazurkiewicz B, Marat L, Dmoch-Gajzlerska M. Wiedza położnic na temat okresu połogu w opinii położnych. Zdrowie i Dobrostan. 2014; 1: 79-97.

23. Warren JB, Phillipi CA. Care of the well newborn. Pediatr Rev. 2012 Jan;33(1):4-18. doi: 10.1542/pir.33-1-4. Erratum in: Pediatr Rev. 2012 Mar;33(3):109. Erratum in: Pediatr Rev. 2013 Jan;34(1):46. PMID: 22210929.

24. Lau C. Development of infant oral feeding skills: what do we know? Am J Clin Nutr. 2016 Feb;103(2):616S-21S. doi: 10.3945/ajcn.115.109603. Epub 2016 Jan 20. PMID: 26791183 ; PMCID: PMC4733254.

25. Łapecka-Klusek C. red. Pielęgniarstwo we współczesnym położnictwie i ginekologii. Podręcznik dla studentów studiów pielęgniarskich, studiów licencjackich. Wydawnictwo CZELEJ Sp. Z. o. o. Lublin 2003: 199-227.

26. Marianowski J. Od poczęcia do narodzin. Poradnik dla przyszłych rodziców. PZWL. Warszawa 2012; 10-17.

27. Ustawa $\mathrm{z}$ dnia 27 sierpnia 2004 roku o świadczeniach opieki zdrowotnej finansowanych ze środków publicznych- art. 5 Dz. U. 2004 Nr 210 poz. 2135 z późn.zm.

28. Rozporządzenie Ministra Zdrowia z dnia 20 września 2012 roku w sprawie standardów postępowania medycznego przy udzielaniu świadczeń zdrowotnych $\mathrm{z}$ zakresu opieki okołoporodowej sprawowanej nad kobietą w okresie fizjologicznej ciąży, fizjologicznego porodu, połogu oraz opieki nad noworodkiem Dz. U. 2012 poz. 1100.

29. Iwanowicz-Palus GJ, Gross E. Kształcenie położnych w Polsce a prezentowane modele opieki okołoporodowej. Międzynarodowy Kongres „Witajcie na świecie- o perspektywach i kierunkach rozwoju światowego i polskiego położnictwa”. Pielęgniarka i Położna. 2007; 1: 23-26.

30. Rozporządzenie Ministra Zdrowia z dnia 16 sierpnia 2018 roku w sprawie standardu organizacyjnego opieki okołoporodowej, Dz. U. z 2018r., poz. 1756.

31. Rozporządzenie Ministra Zdrowia z dnia 21 września 2016 roku w sprawie zakresu zadań lekarza podstawowej opieki zdrowotnej, pielęgniarki podstawowej opieki zdrowotnej i położnej podstawowej opieki zdrowotnej, Dz. U. z 2016, poz. 1567. 
32. Iwanowicz-Palus G, Krysa J, Bień A. Rola położnej rodzinnej w Polsce. Medycyna Ogólna i Nauki o Zdrowiu. 2013; 19(3): 272-278.

33. Biskupska M, Niewiadomski TJ. Współpraca położnych podstawowej opieki zdrowotnej z podmiotami świadczącymi opiekę nad kobietami, noworodkami i niemowlętami do drugiego miesiąca życia. Problemy Pielęgniarstwa. 2009; 17(4): 301-305. 